\title{
Kapasitas Petani Penangkar Benih Padi di Kabupaten Majalengka: Peran Penyuluhan dan Kelompok Tani
}

\section{The Capacity of Rice Seed Breeding Farmers in Majalengka Regency: The Role of Extension and Farmer Groups}

\author{
Atang Muhammad Safei ${ }^{1, *}$, Siti Amanah ${ }^{2}$, Anna Fatchiya ${ }^{2}$
}

${ }^{1}$ Balai Pengkajian Teknologi Pertanian Jawa Barat, Balitbangtan, Kementerian Pertanian, Jakarta 40391, Indonesia ${ }^{2}$ Program Studi Komunikasi Pembangunan Pertanian dan Pedesaan, Institut Pertanian Bogor, Bogor 16680, Indonesia ${ }^{*}$ E-mail korespondensi: atangbptpjabar@yahoo.com

Diterima: 3 Mei 2021 | Disetujui: 22 September 2021 | Publikasi Online: 29 September 2021

\section{ABSTRACT}

The availability of certified rice seeds is still limited because the limited number of rice seed breeder farmers.The capacity of farmers in seed assessment and seed production determine the succes of the rice seed breeding. The research using the census method (112 breeder farmers) was conducted in Majalengka Regency. Interviews and observations were carried out to obtain data on extension and breeding of rice seeds by farmers. Partial Least Square (PLS-Path Modeling) was used to analyze the data. The results showed that the suitability of the materials, extension methods and ability of the extension agents were in the medium category, the intensity of extension was still low. Extension officers visit farmer groups once a month. The role of farmer groups and farmer capacity is in the medium category. Farmer groups are able to carry out the learning process and seed production even though the marketing is not continuous. The implementation of extension services and farmer groups has a positive effect on the farmer capacity. The use of social media by breeder farmers for seed marketing and obtaining marketing partners and business capital can be increased through increasing the intensity of extension by involving farmer groups.

Keywords: Capacity of rice seed breeding farmers, effectiveness of extension, role of farmers group

\section{ABSTRAK}

Ketersediaan benih padi bersertifikat rendah karena jumlah penangkar benih terbatas. Kapasitas petani dalam penilaian benih dan produksi benih menentukan keberhasilan usaha penangkaran. Penelitian ini bertujuan untuk menganalisis pengaruh penyuluhan dan peran kelompok tani terhadap kapasitas petani dalam penangkaran benih padi. Penelitian dengan metode sensus (112 petani penangkar) dilakukan di Kabupaten Majalengka. Wawancara dan oberservasi dilakukan untuk memperoleh data mengenai penyuluhan dan penangkaran benih padi oleh petani. Partial Least Square (PLS-Path Modelling) digunakan untuk menganalisis data. Hasil penelitian memperlihatkan bahwa kesesuaian materi, metode penyuluhan dan kemampuan penyuluh berada pada kategori sedang, intensitas penyuluhan masih rendah. Penyuluh melakukan kunjungan ke kelompok tani setiap bulan sekali. Peran kelompok tani dan kapasitas petani berada pada kategori sedang. Kelompok tani mampu menyelenggarakan proses pembelajaran dan produksi benih walaupun pemasaran belum kontinyu. Pelaksanaan penyuluhan dan kelompok tani mempunyai pengaruh positif terhadap tingkat kapasitas petani. Pemanfaatan media sosial oleh petani penangkar untuk pemasaran benih dan memperoleh mitra pemasaraan dan modal usaha dapat ditingkatkan melalui peningkatan intensitas penyuluhan dengan melibatkan kelompok tani.

Kata kunci: kapasitas petani penangkar, efektivitas penyuluhan, peran kelompok tani 



\section{PENDAHULUAN}

Ketersediaan dan penggunaan benih padi bersertifikat di tingkat petani masih terbatas. Pada tahun 2017, tingkat penggunaan benih varietas unggul padi bersertifikat baru mencapai 52,65 persen (Dirjen Tanaman Pangan, 2018). Petani menggunakan benih padi dari hasil panen maupun dari petani lain. Kalaupun petani menggunakan benih bersertifikat, benih tersebut bukan merupakan benih unggul rekomendasi pemerintah dengan potensi hasil tinggi tetapi benih yang sudah mengalami pelandaian produksi dan cenderung rentan terhadap serangan hama dan penyakit.

Salah satu penyebab produksi benih bersertifikat rendah adalah jumlah penangkar benih padi terbatas. Optimalisasi kelompok tani sebagai penangkar benih dapat meningkatkan produksi benih sehingga akses petani pada benih menjadi lebih mudah karena benih tersedia di wilayah petani. Kapasitas petani dalam menilai kualitas dan produksi benih padi menentukan keberhasilan usaha penangkaran benih. Menurut Fatchiya (2010) kapasitas petani merupakan kemampuan petani dalam menjalankan fungsi usaha, memecahkan masalah, serta merencanakan dan mengevaluasi usaha untuk mendapatkan keberlanjutan usaha. Sementara itu UNDP, (2008) mendefinisikan kapasitas sebagai kemampuan individu, lembaga, organisasi dan masyarakat untuk menjalankan fungsi-fungsi, memecahkan masalah, menyusun serta mencapai tujuan secara efektif, efisien dan berkelanjutan. Kapasitas petani dalam usaha penangkaran masih terbatas sehingga memengaruhi mutu hasil produksi benih (Putra et al., 2016). Peningkatan kapasitas petani pada usaha penangkaran benih dapat dilakukan melalui kegiatan penyuluhan (Tjitropranoto, 2005) sehingga kinerja agribisnis lebih baik (Iskandar et al., 2020) dan pemberdayaan kelompok (Saleh et al., 2016).

Kegiatan penyuluhan meliputi pembelajaran mengenai teknologi usaha penangkaran benih sehingga diperoleh perubahan kapasitas petani dalam produksi benih berkualitas baik (Amanah, 2014). Pencapaian tujuan pembelajaran pada kegiatan penyuluhan dapat dipengaruhi oleh intensitas penyuluhan dan kemampuan penyuluh dalam menyampaikan materi penyuluhan yang sesuai dengan kebutuhan petani melalui metode penyuluhan yang tepat. Penyuluhan dengan melibatkan kelompok tani dapat memperlancar sistem penyuluhan dari petani ke petani. Petani maju lebih efektif dalam berperan menyampaikan inovasi kepada petani lainnya karena sudah memahami dan menguasai keadaan mereka (Haryanto et al., 2020).

Kegiatan penyuluhan dalam upaya peningkatan kapasitas petani dapat didukung melalui optimalisasi peran kelompok tani. Kelompok tani mempunyai peran strategis dalam peningkatan pengetahuan, sikap dan ketrampilan anggota kelompok. Permentan, (2013) menyebutkan peran kelompok tani dalam pengembangan usaha penangkaran benih padi dapat berperan sebagai kelas belajar, wahana kerjasama, dan unit produksi. Menurut Slamet, (2001), pendekatan kelompok dapat menjadi media proses belajar dan berinteraksi sehingga dapat terjadi perubahan perilaku.

Penelitian terkait kapasitas petani dan penangkaran benih padi di antaranya adalah hubungan dinamika dan peran kelompok tani dengan kapasitas petani penangkar (Putra et al., 2016), strategi meningkatkan kapasitas petani (Saleh et al., 2016), analisis kelayakan usahatani penangkaran benih (Erwandri, 2020), analisis pendapatan dan faktor yang memengaruhi keputusan usahatani penangkaran benih padi (Mita et al., 2018), peningkatan pengetahuan petani melalui sekolah produksi benih padi (Tin et al., 2010). Berbagai hasil penelitian tersebut belum mengungkapkan bagaimana efektivitas penyuluhan dan optimalisasi peran kelompok tani dalam mendukung peningkatan kapasitas petani penangkar benih padi sehingga menghasilkan produksi benih padi yang berkualitas. Oleh karena itu, penelitian kapasitas petani penangkar benih padi dilihat pada peran penyuluhan dan kelompok tani ini sangat penting untuk dilakukan. Dengan latar belakang tersebut, penelitian ini bertujuan untuk menganalisis tingkat kapasitas petani penangkar benih padi, serta pengaruh efektivitas penyuluhan dan peran kelompok tani terhadap kapasitas petani dalam penangkaran benih padi.

\section{METODE PENELITIAN}

Lokasi penelitian ditentukan secara purposive dengan pertimbangan bahwa di Kabupaten Majalengka terdapat program Desa Mandiri Benih (DMB). Penyuluhan penangkaran benih di kabupaten ini dilakukan secara intensif dan terdapat kelompok tani yang menjadi juara pertama tingkat nasional DMB. Data lapangan dikumpulkan mulai Desember 2020 sampai Januari 2021.

Penelitian ditentukan dengan cara sensus yaitu dengan unit analisis seluruh anggota kelompok tani penangkar (112 orang) yang merupakan petani kooperator program DMB di Kabupaten Majalengka. Petani responden tersebut terdiri atas 48 orang anggota kelompok tani Gangsa I (Desa Jatitengah, Kecamatan Jatitujuh), 30 orang 
anggota kelompok tani Guna Tani (Desa Babakan Manjeti, Kecamatan Sukahaji) dan 34 orang anggota kelompok tani Sukamaju II (Desa Sukamaju, Kecamatan Kertajati).

Data primer dikumpulkan melalui observasi langsung, wawancara menggunakan kuesioner kepada responden serta wawancara mendalam kepada key person, yaitu peneliti, teknisi penelitian dan perekayasaan (litkayasa), penyuluh, ketua dan pengurus kelompok tani. Data yang dikumpulkan meliputi efektivitas penyuluhan $\left(\mathrm{X}_{1}\right)$, peran kelompok tani $\left(\mathrm{X}_{2}\right)$ dan kapasitas petani dalam usaha penangkaran benih padi (Y). Kuantifikasi data primer menggunakan skala Likert dengan kategori sangat rendah (skor 1), rendah (skor 2), sedang (skor 3) dan tinggi (skor 4). Efektivitas penyuluhan $\left(\mathrm{X}_{1}\right)$, dan peran kelompok tani $\left(\mathrm{X}_{2}\right)$ diduga mempunyai pengaruh pada kapasitas petani dalam usaha penangkaran benih padi/Y (Gambar 1). Persamaan model struktural PLS nya adalah $\mathrm{Y}=\lambda_{1} \mathrm{X}_{1}+\lambda_{2} \mathrm{X}_{2}+\varsigma$. Dimana $\lambda$ merupakan nilai koefisien jalur dan $\varsigma$ menggambarkan inner residual variabel.

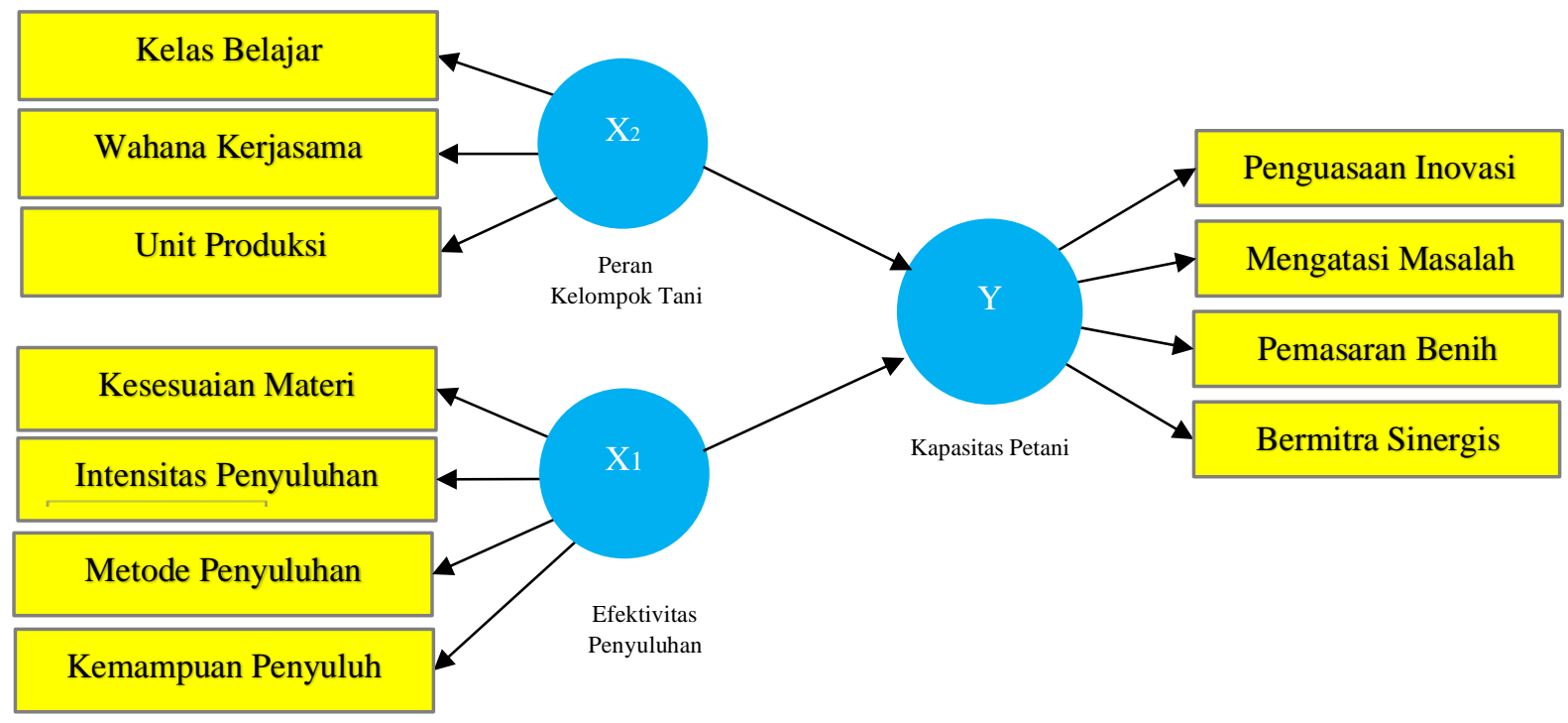

Gambar 1. Hubungan antara peubah bebas dan peubah tidak bebas

Data sekunder dikumpulkan dari Dinas Tanaman Pangan dan Hortikultura, Balai Pengawasan dan Sertifikasi Benih Tanaman Pangan dan Hortikultura (BPSBTPH), Balai Pengkajian Teknologi Pertanian (BPTP) Provinsi Jawa Barat, Dinas Ketahanan Pangan Pertanian dan Perikanan, Badan Pusat Statistik (BPS) Kabupaten Majalengka, Balai Penyuluhan Pertanian (BPP) Kecamatan Jatitujuh, Jatiwangi dan Kertajati.

Data dianalisis dengan menggunakan statistik deskriptif untuk menjelaskan tingkat efektivitas penyuluhan, peran kelompok tani dan tingkat kapasitas petani. Analisis Partial Least Square (PLS) dengan aplikasi Smart PLS3 digunakan menguji pengaruh efektivitas penyuluhan dan peran kelompok tani terhadap kapasitas petani penangkar benih. Model pengukuran (outer model) digunakan untuk menilai validitas konstruk dan reliabilitas dari peubah melalui proses literasi algoritma untuk mendapatkan parameter model pengukuran. Model pengukuran dapat menspesifikasi hubungan antar variabel laten dengan indikator-indikatornya. Untuk penelitian yang bersifat confirmatory, parameter validitas konvergen yang dinilai adalah loading factor $>0,7$ (outer loading), Average Variance Extracted (AVE) > 0,5. Uji reliabilitas dilakukan untuk membuktikan akurasi, konsistensi dan ketepatan instrumen dalam mengukur konstruk. Reliabilitas dinilai berdasarkan nilai composite reliability yaitu $>0,7$. Uji reliabilitas diperkuat dengan nilai Cronbach Alpha $>0,7$ untuk semua konstruk.

Model struktural (inner model) digunakan untuk menilai kekuatan estimasi antar peubah laten sehingga dapat diketahui kekuatan model. Analisa model struktural dilakukan melalui proses bootstraping. Penilaian model struktural menggunakan nilai $\mathrm{R}^{2}$ untuk mengukur tingkat variasi perubahan variabel independen terhadap variabel dependen. Semakin besar nilai $\mathrm{R}^{2}$ semakin baik model prediksi dari model penelitian yang diajukan. Menurut Ghosali \& Latan, (2015) nilai $\mathrm{R}^{2} 0.75,0.50,0.25$ disimpulkan bahwa model kuat, moderat, dan lemah. 


\section{HASIL DAN PEMBAHASAN}

\section{Tingkat Kapasitas Petani Penangkar Benih Padi}

Kapasitas petani merupakan tingkat pemahaman dan kemampuan petani untuk melakukan usaha penangkaran benih padi, yaitu penguasaan inovasi penangkaran benih padi, kemampuan petani dalam mengatasi masalah, pemasaran benih padi dan bermitra sinergis. Kapasitas petani penangkar pada semua indikator berada pada kategori sedang (Tabel 1). Terdapat perbedaan yang nyata pada semua indikator kapasitas petani di antara ketiga lokasi penelitian. Rata-rata tingkat kapasitas petani penangkar di kelompok tani Gangsa I lebih tinggi dari pada kapasitas petani di kelompok tani Sukamaju II dan Guna Tani. Petani penangkar di kelompok tani Gangsa I mendapatkan pendampingan usaha penangkaran benih secara lebih intensif oleh berbagai pihak seperti BPTP, Dinas Pertanian, BBPadi, BPSBTPH serta pihak swasta.

\section{Penguasaan Inovasi Penangkaran Benih}

Kapasitas petani penangkar pada penguasaan inovasi penangkaran benih berada pada kategori sedang cenderung tinggi, dengan nilai rataan 69,57 (Tabel 1) dan merupakan skor paling tinggi di antara indikator peubah lainnya. Hal ini mengindikasikan bahwa kemampuan petani dalam proses budidaya, sertifikasi benih, kegiatan rouging dan penanganan pasca panen tergolong baik sehingga menunjang keberhasilan usaha penangkaran benih padi.

Pada aspek proses budidaya, petani telah mengenal sistem budidaya pertanian dengan baik. Petani mengetahui berbagai jenis VUB padi yang mempunyai potensi hasil tinggi. Petani mengerti penerapan sistem tanam jajar legowo dapat meningkatkan hasil dari pada sistem tanam tegel. Pada pengendalian hama dan penyakit, petani sadar bahwa pengendalian harus dilakukan secara ramah lingkungan. Pengendalian hama dan penyakit berdasarkan tingkat serangan dan menggunakan pestisida nabati.

Petani menggunakan varietas unggul baru yang dilepas oleh pemerintah seperti Inpari 32, Inpari 39, Inpari 42, Inpari 43, Inpari 45 dan NutriZinc. Dalam menentukan dosis pemupukan, petani menggunakan alat PUTS (Perangkat Uji Tanah Sawah) sesuai dengan rekomendasi penyuluh pertanian. Akan tetapi, inovasi berupa penggunaan alat mesin pertanian belum dapat diterapkan oleh petani. Petani masih kesulitan dalam membuat bibit tanam untuk menggunakan mesin rice transplanter, kondisi lahan yang memerlukan syarat tidak berlumpur untuk menggunakan combine harvester sulit terpenuhi.

Tabel 1. Tingkat kapasitas petani penangkar benih padi di kabupaten Majalengka

\begin{tabular}{|c|c|c|c|c|c|c|}
\hline \multirow{3}{*}{ Peubah } & \multirow{3}{*}{ Kategori } & \multicolumn{3}{|c|}{ Kelompok Tani } & \multirow{3}{*}{$\begin{array}{r}\text { Total } \\
\mathbf{n}=112\end{array}$} & \multirow{3}{*}{$\begin{array}{c}\text { Uji } \\
\text { Beda } \\
\text { Kruskal } \\
\text { Wallis }\end{array}$} \\
\hline & & Gangsa I & Sukamaju II & Guna Tani & & \\
\hline & & $\begin{array}{c}\mathrm{n}=\mathbf{4 8} \\
\%\end{array}$ & $\begin{array}{c}\mathrm{n}=34 \\
\%\end{array}$ & $\begin{array}{c}\mathrm{n}=\mathbf{3 0} \\
\%\end{array}$ & & \\
\hline \multirow{4}{*}{$\begin{array}{l}\text { Penguasaan inovasi } \\
\text { penangkaran (skor) } \\
\text { Rataan }=69,57\end{array}$} & Sangat Rendah & 0 & 2,9 & 6,7 & 0,9 & \multirow{4}{*}{$0,000^{*}$} \\
\hline & Rendah & 2.1 & 32.4 & 66.7 & 12.5 & \\
\hline & Sedang & 43,7 & 58,8 & 26,6 & 54,5 & \\
\hline & Tinggi & 54,2 & 5,9 & 0 & 32,1 & \\
\hline \multirow{4}{*}{$\begin{array}{l}\text { Mengatasi Masalah } \\
\text { (skor) } \\
\text { Rataan }=64,16\end{array}$} & Sangat Rendah & 0 & 8,8 & 0 & 2,7 & \multirow{4}{*}{$0,000^{*}$} \\
\hline & Rendah & 6,2 & 14,7 & 3,3 & 7,1 & \\
\hline & Sedang & 62,5 & 73,6 & 86,7 & 73,2 & \\
\hline & Tinggi & 31,3 & 2,9 & 10 & 17,0 & \\
\hline \multirow{4}{*}{$\begin{array}{l}\text { Pemasaran Benih } \\
\text { (skor) } \\
\text { Rataan=65,89 }\end{array}$} & Sangat Rendah & 0 & 8,8 & 0 & 2,7 & \multirow{4}{*}{$0,001 *$} \\
\hline & Rendah & 0 & 14,7 & 3,3 & 5,4 & \\
\hline & Sedang & 58,3 & 73,5 & 86,7 & 70,5 & \\
\hline & Tinggi & 41,7 & 2,9 & 10,0 & 21,4 & \\
\hline \multirow{4}{*}{$\begin{array}{l}\text { Bermitra Sinergis } \\
\text { (skor) } \\
\text { Rataan=64,93 }\end{array}$} & Sangat Rendah & 0 & 8,8 & 0 & 2,7 & \multirow{4}{*}{$0,000^{*}$} \\
\hline & Rendah & 4,2 & 20,6 & 10 & 10,7 & \\
\hline & Sedang & 68,7 & 70,6 & 80 & 72,3 & \\
\hline & Tinggi & 27,1 & 0 & 10 & 14,3 & \\
\hline
\end{tabular}

Keterangan: Skor indeks: sangat rendah 0-25; rendah 26-50; sedang 51-75; tinggi 76-100

$* *$ ) berbeda sangat nyata pada $\leq 0,01$ 
Petani mengetahui pendaftaran sertifikasi benih harus dilakukan sebelum tanam dengan melampirkan label benih. Oleh karena itu, petani menyimpan dan mengumpulkan label benih pada pengurus kelompok setelah mereka melakukan penyemaian. Benih yang ditanam petani adalah kelas SS dengan label warna ungu. Petani belum mampu mendaftar sertifikasi online ke BPSBTPH sehingga pendaftaran dilakukan secara kolektif oleh pengurus kelompok.

Petani mengetahui proses pelaksanaan rouging. Rouging merupakan kegiatan membuang rumpun tanaman yang ciri morfologisnya berbeda dari varietas tanaman yang benihnya akan diproduksi. Kegiatan rouging dilakukan antara 3-4 kali selama proses budidaya, yaitu fase vegetatif dan generatif. Akan tetapi untuk pelaksanaan rouging, kemampuan petani masih perlu ditingkatkan. Rouging yang dilakukan petani masih terdapat campuran varietas lain (CVL) di hamparan sawah. Untuk menghindari kegagalan sertifikasi benih, sebelum petugas BPSBTPH melakukan pemeriksaan lapang, tim rouging melakukan pemeriksaan tanaman padi petani dan melakukan rouging apabila masih ditemukan CVL.

Pada penanganan pasca panen, petani mempunyai kemampuan yang baik. Petani paham bahwa pengeringan gabah harus mencapai kadar air 12 persen sehingga kualitas benih dapat bertahan. Petani mengetahui bahwa benih harus disimpan di tempat yang kering dan tidak menyentuh lantai secara langsung. Benih harus dibersihkan dari kotoran karena dapat memengaruhi kualitas benih. Akan tetapi, adakalanya calon benih yang dihasilkan belum mencapai kadar air 12 persen. Hal ini karena keterbatasan lantai jemur dan ketiadaan alat untuk mengukur kadar air gabah. Selain itu, petani belum sempurna dalam membersihkan kotoran pada calon benih. Kelompok tani masih harus membersihkan kotoran menggunakan seed cleaner sebelum benih dikemas dan dipasarkan.

\section{Mengatasi Masalah}

Kapasitas petani pada aspek mengatasi masalah merupakan kemampuan petani dalam menghadapi kendala dalam usaha penangkaran benih. Kemampuan ini diukur dari pemahaman terhadap masalah, kemauan mencari solusi permasalahan dan usaha menyelesaikan masalah yang dihadapi dalam usaha penangkaran benih. Pada aspek mengatasi masalah, kapasitas petani berada pada kategori sedang dengan rataan 64,16 . Secara umum, kemampuan petani sebesar 73,2 persen berada pada kategori sedang dan 17,0 persen berada pada kategori tinggi. Hal ini menunjukkan bahwa kemampuan petani dalam mengatasi masalah cukup baik. Akan tetapi, indikator mengatasi masalah merupakan indikator paling rendah di antara indikator kapasitas petani penangkar yang lain.

Untuk menunjang keberhasilan usaha penangkaran benih, kelompok tani mengadakan diskusi dengan anggota mengenai hambatan dan tantangan dalam usaha penangkaran benih. Salah satu permasalahan yang dihadapi petani penangkar adalah pemenuhan pupuk, pestisida, modal usaha dan pemasaran produksi. Pada umumnnya petani mempunyai lahan sempit dengan modal terbatas. Harapan petani adalah segera mendapat uang dari hasil panen untuk biaya tanam padi pada masa tanam berikutnya. Kebutuhan ini terkadang membuat petani menjual calon benih dengan harga konsumsi. Petani lebih mudah menjual gabah konsumsi dari pada benih.

Kelompok tani berupaya mencegah hal ini dengan membeli calon benih petani dengan harga Rp 200,- lebih tinggi dari harga konsumsi. Modal usaha kelompok tani untuk membeli calon benih petani, diperoleh melalui kerjasama pemasaran dengan pihak swasta. Akan tetapi, jumlah kemitraan dengan swasta terbatas dan belum berkelanjutan. Penjualan di kios tani membutuhkan waktu, karena kemitraan dengan kios tani menggunakan sistem penitipan. Kios tani melakukan pembayaran ketika benih sudah terjual. Kemampuan pemasaran kelompok tani terbatas, sehingga tidak semua produksi anggota tertampung.

Kelompok tani dapat menyelesaikan memecahkan permasalahan yang dihadapi petani dalam hal kekurangan pupuk dan serangan hama. Dalam hal kekurangan pupuk dan pestisida, kelompok tani melakukan identifikasi kebutuhan pupuk dan pestisida di saat menjelang tanam. Kelompok tani menyusun e-RDKK untuk melaporkan kebutuhan pupuk kepada penyuluh. Kelompok tani menyediakan sarana produksi berupa benih, pupuk dan pestisida. Untuk mengantisipasi serangan hama, kelompok tani melakukan monitoring ke lahan usahatani anggota kelompok. Apabila diperlukan, kelompok tani melakukan gerakan pengendalian hama dan penyakit dengan bekerjasama dengan petugas POPT. 
Menurut van den Ban \& Hawkins, (1999) diagnosis masalah yang tepat harus dilakukan karena memahami penyebab suatu masalah sangat penting sebelum mengambil keputusan solusi pemecahannya. Kelompok tani berupaya menyelesaikan permasalahan anggota dan kelompok tani melalui diskusi. Dengan dialog tersebut, dapat diketahui akar permasalahan petani terutama terkait produksi benih padi maupun pemasaran produk petani. Kelompok tani dapat menyakinkan petani untuk menjual hasil produksi berupa benih.

\section{Pemasaran Benih}

Pada aspek pemasaran benih, kapasitas petani berada pada kategori sedang dengan rataan 65,89 . Petani dapat merencanakan luas lahan dan jenis varietas pada produksi benih padi yang akan datang. Petani melalui kelompok tani melaksanakan pemasaran hasil, akses harga pasar dan lembaga pemasaran.

Perencanaan pemasaran harus dilakukan dengan baik untuk menjamin keberhasilan usaha penangkaran. Kelompok tani melakukan survei mengenai preferensi petani pada varietas padi dan berpotensi besar untuk dikembangkan. Mereka melakukan survei melalui diskusi dengan sesama petani, menyebarkan kuesioner pada pelaksanaan demplot/display VUB padi serta wawancara dengan kios tani mengenai jenis varietas padi yang paling dicari oleh petani.

Kemampuan kelompok tani dalam menampung benih padi terbatas, sehingga petani menyusun rencana produksi dan pemasaran. Kelompok mengidentifikasi kemampuan kios tani, pihak mitra dalam menampung benih padi sehingga jumlah dan varietas padi dapat ditentukan. Kelompok tani Sukamaju II melakukan produksi jika ada permintaan benih dari swasta maupun pemerintah. Kelompok tani Guna Tani memproduksi 30 ton benih Inpari 32 karena ada jaminan dari mitra pedagang. Kelompok tani Gangsa I memproduksi 300 ton setelah menghitung kemampuan serapan dari kios tani, pihak swasta dan kerjasama pengadaan benih dengan pemerintah.

Dalam bidang pemasaran, petani belum memanfaatkan media sosial secara optimal. Kelompok tani Gangsa I menggunakan akun facebook Poktan Gangsa I untuk menginformasikan kegiatan kelompok walaupun belum rutin dan up to date. Petani menggunakan kelompok whatsapp penangkar benih untuk mengakses informasi pasar benih. Di sisi lain, kelompok tani Guna Tani dan Sukamaju II bahkan tidak mempunyai akun facebook maupun whatsapp untuk pengembangan usaha penangkaran benih.

Salah satu upaya kelompok tani mengakses lembaga pemasaran adalah melalui pameran. Kelompok tani mengikuti pameran pertanian yang ada di wilayah Kabupaten Majalengka. Setiap tahun, pemerintah Kabupaten Majalengka mengadakan kegiatan pameran dalam rangka perayaan Hari Krida Pertanian dan Hari Pangan Sedunia. Dalam pameran ini, kelompok tani memperkenalkan profil kelompok tani dan produksi benih VUB padi.

\section{Bermitra Sinergis}

Kapasitas petani dalam aspek bermitra sinergis termasuk dalam kategori sedang dengan rataan 64,93 persen. Petani mengetahui pihak yang dapat bekerjasama untuk penangkaran benih padi seperti PT Pertani, PT SHS, formulator pupuk dan pestisida, bank, kios pertanian serta kelompok penangkar. Kelompok tani Gangsa I bermitra dengan Bank BJB dalam kegiatan resi gudang. Kemitraan dengan pihak swasta belum mampu menampung semua produksi benih kelompok tani. PT Pertani dan PT SHS terbatas untuk jumlah pembelian sekitar 150 ton. Kios pertanian menyerap 1 ton benih per musim. Padahal potensi lahan petani penangkar masih besar untuk meningkatkan produksi benih. Luas lahan petani penangkar mencapai lebih dari 134 ha dengan potensi produksi 670 ton baru mencapai realisasi produksi 300 ton. Kelompok tani Guna Tani bermitra pada kelompok tani Gangsa I dalam pemasaran benih. Kelompok tani Sukamaju II bermitra dengan pemerintah dalam penyediaan benih bersubsidi. Kemitraan pada kelompok Sukamaju II belum berlajan secara kontinyu setiap musim.

Petani berusaha memenuhi persyaratan bermitra dalam penjualan. Kelompok tani bermitra dengan kios tani, individu, pemerintah dan swasta (PT Pertani dan PT SHS). Pada awal musim tanam, kelompok melakukan perencanaan kemitraan. Petani menilai keuntungan dan kerugian dalam kerjasama dengan mitra. Kemitraan dapat tercapai jika prosedur kerjasama mudah, sistem penetapan harga dan pembayaran yang baik, serta petani mudah mencapai standar mutu (Purnaningsih, 2007). Dengan adanya kemitraan, kelompok tani mendapatkan jaminan pasar, akses modal usaha, informasi teknologi penangkaran benih serta keberlanjutan usaha 
penangkaran. Hal ini sesuai Munirudin et al., (2020) yang menyatakan kemitraan memberikan dampak positif pada kesejahteraan petani melalui peningkatan pendapatan, bantuan input produksi, bimbingan budidaya, kemudahan akses pasar, kemudahan layanan kredit serta pihak mitra mempunyai komitmen terhadap kesejahteraan petani.

Kelompok tani penangkar saling bekerjasama dengan dalam penyediaan sarana produksi, keterbatasan kemampuan teknis produksi dan pemasaran, serta pemenuhan produksi calon benih untuk mengatasi keterbatasan lahan. Kelompok tani Guna Tani mengambil calon benih dan memasarkan benih ke kelompok tani Gangsa I. Kelompok tani Gangsa I memberikan pendampingan teknis rouging pada kelompok tani Guna Tani. Kelompok tani Sukamaju belum bekerjasama secara intensif dalam pemasaran benih dengan swasta. Kelompok tani ini bekerjasama dengan pemerintah dan swasta jika ada program pengadaan benih bersubsidi.

Kelompok tani bekerjasama dengan pemerintah dalam kegiatan demplot perbenihan dan uji adaptasi VUB padi. Pemerintah memberikan pendampingan penerapan teknnologi melalui penyuluh lapangan. Demplot ini bertujuan memperlihatkan kinerja teknologi VUB dalam meningkatkan hasil padi sehingga tumbuh kesadaraan petani pada penggunaan benih VUB padi bersertifikat. Dengan kerjasama ini, kelompok tani dapat memproduksi varietas padi yang belum ada di pasaran secara efektif dan efisien.

\section{Efektivitas Penyuluhan dalam Meningkatkan Kapasitas Petani Penangkar Benih}

Untuk mendorong keberhasilan usaha penangkaran benih petani, pemerintah melibatkan kelompok tani dalam setiap proses kegiatan penyuluhan. Penyelenggaraan penyuluhan dapat berjalan dengan baik jika didukung oleh pengembangkan masyarakat petani melalui kelompok tani (Sucihatiningsih, 2010). Penyuluh pertanian melaksanakan kegiatan penyuluhan secara intensif selama program DMB dengan melakukan pendampingan pada setiap proses penangkaran benih padi. Penyuluh memfasilitasi petani mendapatkan benih sumber, mendorong petani menjalin kerjasama dengan kios tani, gapoktan dan kelompok tani lain untuk menggunakan benih produksinya serta memfasilitasi pertemuan peneliti atau POPT ketika tanaman padi petani terserang hama. Kegiatan penyuluhan pada kelompok tani adalah sekolah lapang produksi benih, pengendalian hama dan penyakit, uji adaptasi varietas padi serta teknis rouging.

Tabel 2. Penilaian responden terhadap efektivitas penyuluhan dalam meningkatkan kapasitas petani penangkar benih padi di Kabupaten Majalengka

\begin{tabular}{|c|c|c|c|c|c|c|}
\hline \multirow{3}{*}{$\begin{array}{l}\text { Efektivitas } \\
\text { Penyuluhan }\end{array}$} & \multirow{3}{*}{ Kategori } & \multicolumn{3}{|c|}{ Kelompok Tani } & \multirow{3}{*}{$\begin{array}{l}\text { Total } \\
\mathrm{n}=112\end{array}$} & \multirow{3}{*}{$\begin{array}{c}\text { Uji Beda } \\
\text { Kruskal } \\
\text { Wallis }\end{array}$} \\
\hline & & Gangsa I & Sukamaju II & Guna Tani & & \\
\hline & & $\begin{array}{c}\mathrm{n}=48 \\
\%\end{array}$ & $\begin{array}{c}n=34 \\
\%\end{array}$ & $\begin{array}{c}\mathrm{n}=30 \\
\%\end{array}$ & & \\
\hline \multirow{4}{*}{$\begin{array}{l}\text { Kesesuaian materi } \\
\text { penyuluhan (skor) } \\
\text { Rataan=68,82 }\end{array}$} & Sangat rendah & 0 & 11,8 & 0 & 3,6 & \multirow{4}{*}{$0,002^{*}$} \\
\hline & Rendah & 4,2 & 14,7 & 3,3 & 7,1 & \\
\hline & Sedang & 83,3 & 67,6 & 73,3 & 75,9 & \\
\hline & Tinggi & 12,5 & 5,9 & 23,4 & 13,4 & \\
\hline \multirow{4}{*}{$\begin{array}{l}\text { Intensitas } \\
\text { penyuluhan (skor) } \\
\text { Rataan=50,74 }\end{array}$} & Sangat rendah & 6,3 & 29,4 & 0 & 11,6 & \multirow{4}{*}{$0,000^{*}$} \\
\hline & Rendah & 60,4 & 61,8 & 6,7 & 46,4 & \\
\hline & Sedang & 25,0 & 8,8 & 70,0 & 32,2 & \\
\hline & Tinggi & 8,3 & 0 & 23,3 & 9,8 & \\
\hline \multirow{4}{*}{$\begin{array}{l}\text { Metode } \\
\text { penyuluhan (skor) } \\
\text { Rataan }=63,87\end{array}$} & Sangat rendah & 2,1 & 17,7 & 0 & 6,3 & \multirow{4}{*}{$0,000^{*}$} \\
\hline & Rendah & 6,2 & 14,7 & 3,3 & 8,9 & \\
\hline & Sedang & 75,0 & 64,7 & 83,3 & 73,2 & \\
\hline & Tinggi & 16,7 & 2,9 & 13,4 & 11,6 & \\
\hline \multirow{4}{*}{$\begin{array}{l}\text { Kemampuan } \\
\text { penyuluh (skor) } \\
\text { Rataan }=65,99\end{array}$} & Sangat rendah & 4,2 & 3,0 & 0 & 2,7 & \multirow{4}{*}{$0,000^{*}$} \\
\hline & Rendah & 4,2 & 23,5 & 3,3 & 8,0 & \\
\hline & Sedang & 68,7 & 64,7 & 73,3 & 70,5 & \\
\hline & Tinggi & 22,9 & 8,8 & 23,4 & 18,8 & \\
\hline
\end{tabular}

Keterangan: Skor indeks: sangat rendah 0-25; rendah 26-50; sedang 51-75; tinggi 76-100

$* *$ ) berbeda sangat nyata pada $\leq 0,01$ 
Tabel 2 menunjukkan efektivitas penyuluhan pada aspek kesesuaian materi, metode penyuluhan dan kemampuan penyuluh termasuk dalam kategori sedang, sedangkan intensitas penyuluhan berada pada kategori rendah. Materi penyuluhan yang diberikan oleh penyuluh sesuai dengan minat dan kebutuhan petani, yaitu teknologi budidaya sebagai upaya peningkatan produktivitas dan efisiensi usahatani. Penyuluh menerapkan metode penyuluhan secara tepat. Penyuluh menerapkan berbagai metode penyuluhan untuk menyampaikan materi penyuluhan. Kemampuan penyuluh dalam melaksanakan penyuluhan sedang. Penyuluh memperagakan penerapan inovasi baru kepada petani. Pada aspek intensitas penyuluhan, petani merasa penyuluh kurang melakukan kunjungan ke petani.

\section{Kesesuaian Materi Penyuluhan}

Kesesuaian materi penyuluhan terhadap kebutuhan petani mempunyai rataan skor 68,82 artinya cukup sesuai. Sebanyak 91,1 persen petani menyatakan materi penyuluhan sesuai dengan minat dan kebutuhan serta dapat mempraktekkan teknologi sehingga produksi benih padi tetap tinggi walaupun ada rumpun padi yang harus dibuang karena proses rouging.

Materi penyuluhan yang dibutuhkan petani masih cenderung pada aspek budidaya. Petani berminat pada inovasi yang mampu meningkatkan produksi, seperti pengendalian hama dan penyakit, pemupukan berimbang, serta teknis rouging. Hal ini sesuai dengan materi penyuluhan yang disampaikan penyuluh. Dalam kegiatan penyuluhan, penyuluh menyampaikan jenis VUB padi, sistem tanam jajar legowo, mekanisasi pertanian seperti rice transplanter, combine, power weeder, penggunaan biodecomposer, pengendalian hama dan penyakit, pemupukan berimbang, serta teknis rouging padi.

Kesesuaian materi penyuluhan dengan minat dan kebutuhan membuat petani mudah menerima inovasi. Petani merasa mampu melaksanakan inovasi sehingga proses produksi benih menjadi lebih efektif sehingga hasil dan pendapatan petani meningkat. Walaupun ada kegiatan rouging yaitu membuang tanaman padi yang berbeda dengan varietas yang diproduksi, produksi benih padi petani tetap meningkat. Hal ini dikarenakan petani menerapkan berbagai inovasi yang disampaikan penyuluh di antaranya varietas unggul baru padi Inpari 32, Inpari 39, Inpari 43 yang mempunyai potensi hasil tinggi.

Materi penyuluhan yang bersifat manajerial seperti pemasaran, kewirausahaan, pemanfaatan internet of things, media sosial belum banyak diberikan kepada petani. Padahal hal ini bisa menjadi salah satu kunci keberhasilan usaha tani penangkaran benih. Hal ini sejalan dengan Ragasa, 2016) yang menyatakan peningkatan pendapatan petani tidak hanya mengandalkan peningkatan produktivitas, tetapi termasuk kemampuan akses pasar melalui peningkatan kapasitas petani dalam merespon pasar. Penyuluhan harus mampu mendorong pemenuhan kebutuhan petani bukan sekedar keinginan petani. Penyuluhan perlu menyadarkan kepada petani pentingnya penguasaan aspek manajerial usaha tani.

\section{Intensitas Penyuluhan}

Intensitas penyuluhan pada usaha penangkaran benih mempunyai rataan skor 50,74 (kategori rendah). Sebanyak 55,4 persen responden menyatakan penyuluh jarang melakukan kunjungan ke petani. Penyuluh mendampingi petani secara intensif ketika program Desa Mandiri Benih masih berjalan. Keterbatasan anggaran untuk kegiatan penyuluhan menyebabkan pendampingan program hanya sampai pada peningkatan kapasitas petani dalam proses produksi. Intensitas kunjungan penyuluh ke kelompok tani menjadi satu bulan sekali setelah program berakhir. Penyuluh menghadiri pertemuan kelompok yang biasa dilakukan pada awal masa tanam. Penyuluh melakukan komunikasi dengan petani ketika ada permasalahan seperti serangan hama dan penyakit serta informasi ketersediaan benih padi.

Intensitas kunjungan ke kelompok tani yang ideal adalah setiap dua minggu sekali. Akan tetapi komposisi jumlah penyuluh tidak sesuai dengan jumlah petani serta cakupan wilayah kerja. Seorang penyuluh dapat mendampingi petani di 2-4 desa, padahal idealnya satu desa didampingi seorang penyuluh. Selain itu, penyuluh mempunyai beban pekerjaan yang bersifat administratif seperti pembentukan kartu tani, Asuransi Usaha Tani Padi (AUTP), e-RDKK, serta laporan luas tambah tanam. Hal ini sejalan dengan Rimbawati et al., (2018) yang menyatakan bahwa faktor utama penyuluh jarang melakukan kunjungan ke kelompok tani adalah jumlah penyuluh yang terbatas dengan wilayah kerja yang sangat luas. 


\section{Metode Penyuluhan}

Metode penyuluhan mempunyai rataan skor 63,87, artinya berada dalam kategori sedang. Penyuluh melibatkan petani dalam proses perencanaan dan pelaksanaan penyuluhan. Penyuluh mengidentifikasi minat, kebutuhan, permasalahan petani dan merencanakan kegiatan penyuluhan untuk mendukung setiap tahap proses produksi benih padi seperti budidaya padi, rouging, dan penanganan pasca panen. Keterlibatan petani dalam penentuan jenis varietas benih padi, penggunaan teknologi serta perencanaan pemasaran meningkatkan peran serta petani dalam pelaksanaan penyuluhan.

Dalam menyampaikan inovasi produksi benih padi, penyuluh menggunakan metode yang beragam, yaitu ceramah, demplot, sekolah lapang, kunjungan lapang dan perorangan, serta penggunaan leaflet dan brosur. Petani menginginkan metode penyuluhan berupa demplot, sekolah lapang, kunjungan lapangan, ceramah dapat dilaksanakan secara kontinyu. Pemilihan metode penyuluhan yang tepat dapat membantu petani memahami materi penyuluhan (Tahitu et al., 2016).

Demplot uji adaptasi VUB padi dan sekolah lapang sistem produksi benih menjadi sarana petani untuk learning by doing. Petani langsung melakukan praktek dan mengamati kinerja inovasi sehingga petani menjadi yakin dan dapat membandingkan dengan kebiasaan usaha tani yang selama ini dijalankan. Hal ini sejalan dengan Mardikanto (1993) yang menyatakan metode demonstrasi merupakan metode yang efektif, karena petani dapat melihat bukti nyata keunggulan inovasi sehingga mereka lebih cepat ingin mencoba dan menerapkan inovasi baru. Akan tetapi, metode demplot dan sekolah lapang hanya dilakukan kalau ada program pemerintah. Ketika program pemerintah berhenti karena keterbatasan anggaran, metode penyuluhan yang dilakukan adalah kunjungan kelompok dengan intensitas terbatas.

\section{Kemampuan Penyuluh}

Kemampuan penyuluh berada pada kategori sedang. Penyuluh menguasai teknologi penangkaran benih seperti teknis budidaya padi, jenis VUB padi, proses rouging, sertifikasi benih serta penanganan pasca panen. Sebelum pelaksanaan program DMB, Dinas terkait memberikan pelatihan kepada penyuluh mengenai proses penangkaran benih padi. Penyuluh berdiskusi dengan pihak pendamping lainnya seperti BPTP, BPSBTPH, serta BPTPH mengenai strategi pengembangan penangkaran benih. Pertemuan dengan penangkar dimanfaatkan penyuluh untuk tukar pengalaman dalam usaha penangkaran benih padi.

Penyuluh memanfaatkan media sosial seperti facebook, youtube dan cyber extention untuk mencari materi penyuluhan. Hal ini sejalan dengan penelitian Suratini et al., (2021) yang menyatakan bahwa penyuluh memanfaatkan media sosial untuk mencari informasi dan menyebarkannya kepada petani. Dengan persiapan tersebut, penyuluh dapat menjelaskan inovasi baru dan menjawab pertanyaan secara lebih detail dan mudah dipahami petani. Penyuluh menggunakan bahasa sederhana yang biasa digunakan sehari-hari oleh petani. Penyuluh memberikan praktek penerapan teknologi proses produksi benih pada pelaksanaan penyuluhan pertanian.

Penyuluh membantu petani menyelesaikan masalah aspek budidaya. Produkvititas petani mencapai 7-9 ton/ha. Penyuluh belum dapat membantu petani dalam pemasaran dan modal usaha. Penyuluh belum mampu memberikan akses informasi pasar dan sumber modal, memfasilitasi bantuan sarana dan prasarana produksi benih padi, seperti mesin pengering gabah, serta seed cleaner.

Penyuluh belum memfasilitasi kerjasama antara petani dengan pihak mitra yang mampu menampung produksi benih secara berkelanjutan. Fasilitasi penyuluh pada pemasaran benih terbatas pada pemenuhan kebutuhan benih untuk kelompok tani lain dan kios tani. Pertemuan dengan pihak mitra dapat dilakukan melalui kegiatan temu usaha, akan tetapi kegiatan ini memerlukan biaya.

\section{Peran Kelompok Tani dalam Meningkatkan Kapasitas Petani Penangkar Benih}

Peran kelompok tani dalam meningkatkan kapasitas petani penangkar sebagai kelas belajar, wahana kerjasama dan unit produksi berada pada kategori sedang (Tabel 3). Peran kelompok tani paling besar adalah sebagai kelas belajar dengan nilai rataan 71,90 diikuti unit produksi $(68,30)$ dan wahana kerjasama $(55,53)$. Terdapat perbedaan yang nyata antara peran kelompok tani di ketiga lokasi penelitian. Dinamika kelompok tani Gangsa I lebih tinggi dari pada kelompok tani Sukamaju II dan Guna Tani. Tokoh masyarakat di kelompok tani Gangsa I menguasai bidang pertanian dan berpartisipasi secara langsung dalam mendukung kegiatan penangkaran benih. Tokoh masyarakat merupakan petani padi yang aktif memberikan informasi teknologi penangkaran benih dan mendorong kerjasama dengan berbagai pihak sehingga kegiatan kelompok menjadi dinamis. Hal ini 
berbeda dengan kelompok tani Guna Tani dan Sukamaju II, tokoh masyarakat merupakan tokoh agama dan tokoh adat yang tidak menguasai ilmu pertanian dan tidak terlibat langsung dalam pertanian.

\section{Kelas Belajar}

Kelompok tani dapat melaksanakan peran sebagai kelas belajar. Hal ini dapat terlihat dari kapasitas petani pada usaha penangkaran benih padi berada pada kategori sedang cenderung tinggi. Menjelang masa tanam, kelompok tani melakukan pertemuan rutin untuk menentukan varietas, luas lahan dan petani penangkar. Kelompok tani mengadakan pembelajaran dengan mendatangkan nara sumber dari 1) BPSBTPH untuk membahas proses sertifikasi dan rouging, 2) BPTPH untuk mengendalikan serangan hama dan penyakit dengan pestisida nabati, 3) BPTP mengenai teknologi sistem tanam jajar legowo, VUB padi serta mekanisasi pertanian serta 4) DKP3 kabupaten Majalengka untuk kelembagaan dan administrasi kelompok. Proses pembelajaran menggunakan metode diskusi dan praktek di lapangan. Narasumber kadang harus membawa infocus (sarana pertamuan) sendiri karena peralatan kelompok terbatas.

Tabel 3. Penilaian responden terhadap peran kelompok tani dalam meningkatkan kapasitas petani penangkar benih padi di Kabupaten Majalengka

\begin{tabular}{|c|c|c|c|c|c|c|}
\hline \multirow{3}{*}{ Peran Kelompok } & \multirow{3}{*}{ Kategori } & \multicolumn{3}{|c|}{ Kelompok Tani } & \multirow{3}{*}{$\begin{array}{c}\text { Total } \\
\mathrm{n}=112 \\
\%\end{array}$} & \multirow{3}{*}{$\begin{array}{c}\text { Uji Beda } \\
\text { Kruskal } \\
\text { Wallis }\end{array}$} \\
\hline & & Gangsa I & Sukamaju II & $\begin{array}{c}\text { Guna } \\
\text { Tani }\end{array}$ & & \\
\hline & & $\begin{array}{c}\mathrm{n}=48 \\
\%\end{array}$ & $\begin{array}{c}\mathrm{n}=34 \\
\%\end{array}$ & $\begin{array}{c}\mathrm{n}=\mathbf{3 0} \\
\%\end{array}$ & & \\
\hline \multirow{4}{*}{$\begin{array}{l}\text { Kelas Belajar } \\
\text { (skor) } \\
\text { Rataan }=71,90\end{array}$} & Sangat rendah & 0 & 0 & 0 & 0 & \multirow{4}{*}{$0,000 * *$} \\
\hline & Rendah & 0 & 20,6 & 0 & 6,2 & \\
\hline & Sedang & 52,1 & 79,4 & 76,7 & 67,0 & \\
\hline & Tinggi & 47,9 & 0 & 23,3 & 26,8 & \\
\hline \multirow{4}{*}{$\begin{array}{l}\text { Wahana } \\
\text { Kerjasama (skor) } \\
\text { Rataan=55,53 }\end{array}$} & Sangat rendah & 0 & 5,9 & 3,3 & 2,7 & \multirow{4}{*}{$0,010 * *$} \\
\hline & Rendah & 18,8 & 41,2 & 23,3 & 26,8 & \\
\hline & Sedang & 62,4 & 52,9 & 73,4 & 62,5 & \\
\hline & Tinggi & 18,8 & 0 & 0 & 8,0 & \\
\hline \multirow{4}{*}{$\begin{array}{l}\text { Unit Produksi } \\
\text { (skor) } \\
\text { Rataan }=68,30\end{array}$} & Sangat rendah & 0 & 8,8 & 0 & 2,7 & \multirow{4}{*}{$0,000 * *$} \\
\hline & Rendah & 0 & 17,7 & 10,0 & 26,8 & \\
\hline & Sedang & 52,1 & 67,6 & 73,3 & 62,5 & \\
\hline & Tinggi & 47,9 & 5,9 & 16,7 & 8,0 & \\
\hline
\end{tabular}

Keterangan: Skor indeks: sangat rendah 0-25; rendah 26-50; sedang 51-75; tinggi 76-100

**) berbeda sangat nyata pada $\leq 0,01$

Kelompok tani mampu menginventarisasi kebutuhan teknologi anggota. Petani merasa kendala utama usahatani berada pada aspek budidaya. Kebutuhan inovasi teknologi kelompok tani di antaranya penggunaan alat mesin pertanian (rice transplanter, combine harvester, dan power weeder), teknis produksi benih padi, serta pengendalian hama dan penyakit tanaman. Proses pembelajaran kelompok tani menekankan pada teknologi peningkatan produksi padi.

Petani menjadi lebih terbuka pada inovasi baru dengan menerapkan sistem tanam legowo, VUB padi (Inpari 32, Inpari 39 dan Inpari 43), serta biodekomposer. Penerapan biodekomposer mempercepat pembusukan dan meningkatkan kadar hara tanah sehingga tidak perlu membakar jerami.

Pertemuan kelompok tani belum dilaksanakan secara rutin setiap bulan. Topik diskusi pada pertemuan kelompok di antaranya perencanaan produksi benih seperti varietas, jumlah produksi, kebutuhan benih, sarana produksi (pupuk dan pestisida) dan penerapan teknologi (sistem tanam jajar legowo, pupuk hayati, penggunaan alsintan serta penyiapan tenaga kerja). Penyuluh pertanian maupun pihak terkait menggunakan pertemuan ini untuk menyampaikan informasi terkait penangkaran benih, program pemerintah, maupun informasi lainnya. Penyuluh pertanian mendorong petani untuk senantiasa menerapkan inovasi baru.

Proses pembelajaran yang dilakukan oleh kelompok tani meningkatkan motivasi anggota kelompok. Hal ini sesuai dengan penelitian Nurmalia et al., (2020) bahwa wahana pembelajaran pada kelompok dapat meningkatkan kapasitas dan produktivitas pembudidaya ikan. Petani yang berhasil melaksanakan usahatani berbagi pengalaman dengan petani lainnya. Petani menjadi lebih disiplin dalam melaksanakan penerapan inovasi penangkaran sesuai dengan anjuran penyuluh melalui kelompok tani. Hal ini sesuai dengan penelitian 
Anantanyu (2011) yang menyatakan bahwa petani tergabung dalam kelompok tani yang dapat menjalankan peran dengan baik dapat meningkatkan kapasitas dan penerapan inovasi.

\section{Wahana Kerjasama}

Penilaian responden terhadap peran kelompok tani sebagai wahana kerjasama termasuk dalam kategori sedang, dengan rataan skor sebesar 55,53. Peran kelompok tani penangkar sebagai wahana kerjasama berupa pelibatan anggota untuk bekerjasama dalam kegiatan kelompok tani. Untuk mencapai produksi benih berdasarkan permintaan benih dari mitra, kelompok menyusun perencanaan usahatani. Jumlah luas lahan, petani penangkar, varietas yang ditanam ditentukan sebelum waktu tanam dan proses pendaftaran sertifikasi. Petani penangkar harus berkomitmen dalam pelaksanaan tatacara budidaya padi sesuai dengan petunjuk sehingga kualitas produksi benih sesuai standar. Petani tidak menjual calon benih kepada pihak lain.

Kelompok tani menyediakan pupuk, pestisida dan benih sumber kepada petani. Petani menerima sarana produksi menjelang tanam dan pembayaran dilakukan setelah panen. Petani menjual hasil produksi ke kelompok tani dengan harga lebih tinggi Rp 200-300,- / kg dari padi konsumsi. Dalam satu hamparan sawah, petani menanam jenis varietas padi yang sama. Petani saling bekerjasama dalam penentuan waktu tanam, pengendalian hama dan penyakit karena waktu tanam dalam satu varietas tidak boleh berbeda jauh.

Kelompok tani membentuk seksi OPT dan seksi Produksi yang bertugas memantau proses produksi benih petani penangkar. Seksi ini mengidentifikasi perkembangan tanaman padi, seperti tingkat serangan hama dan penyakit, penerapan teknologi penangkaran benih, serta kemurnian varietas (ada tidaknya Campuran Varietas Lain/CVL). Tidak semua petani mampu membedakan ciri varietas calon benih dengan varietas lain. Petugas BPSBTPH pernah merekomendasikan rouging ulang karena masih banyak terdapat CVL di hamparan padi. Untuk mencegah hal tersebut, kelompok membentuk tim rouging untuk memastikan tanaman padi bebas dari CVL.

Kelompok tani memfasilitasi proses produksi benih anggota melalui pendaftaran sertifikasi benih pada BPSBTPH secara kolektif. Untuk pendaftaran sertifikasi benih, minimal luas lahan adalah 0,5 hektar dan merupakan sebuah hamparan yang luas untuk menghindari adanya perkawinan silang dengan tanaman sekitar. Dengan proses pendaftaran sertifikasi, pemeriksaan lapangan dan uji laboratorium yang bersifat kolektif, maka proses sertifikasi cenderung lebih efektif dan efisien.

Ketika ada permasalahan, kelompok mengadakan pertemuan kelompok untuk mencari solusi permasalahan petani. Petani kadang menjual calon benih dengan harga konsumsi karena kebutuhan mendesak. Hal ini merugikan kelompok karena dapat memengaruhi pencapaian target produksi benih. Upaya yang dilakukan kelompok tani adalah melakukan pemupukan modal sehingga kelompok dapat membeli calon benih petani. Akan tetapi, skema kerjasama antar anggota kelompok tani dalam pemupukan modal belum berjalan dengan baik. Anggota kelompok belum bersedia melakukan iuran untuk modal kelompok karena keuangan yang terbatas dan kekhawatiran rugi.

\section{Unit Produksi}

Penilaian petani terhadap peran kelompok tani sebagai unit produksi berada pada kategori sedang, dengan rataan skor 68,30. Kelompok tani melakukan upaya pengembangan produksi untuk mendukung usaha penangkaran benih padi. Kelompok tani menyediakan sarana pertanian berupa traktor, rice transplanter, combine harvester dan power threser. Anggota kelompok tani menyewa traktor untuk mengolah sawah dan power threser untuk kegiatan panen padi. Anggota kelompok yang ingin menerapkan pola tanam jajar legowo menggunakan jasa tanam dari kelompok tani. hal ini karena penggunaan rice transplanter dan combine harvester di tingkat lapangan belum optimal. Kondisi lahan sawah berlumpur dan penyediaan bibit tanam sulit membuat penggunaan alsintan ini belum optimal.

Kelompok tani membuat perencanaan kegiatan kelompok untuk mencapai target produksi benih. Jumlah target produksi benih dibagi kepada anggota kelompok. Untuk menghindari terjadinya persilangan, penanaman varietas padi harus disesuaikan dengan luas sawah petani. Terkadang ada petani yang tidak mau menanam varietas padi tertentu, sehingga harus dilakukan diskusi antar anggota untuk menyelesaikan hal tersebut.

Kelompok tani memfasilitasi penyediaan pupuk bersubsidi, pestisida, calon benih unggul yang bersertifikat dan kebutuhan teknologi yang dapat meningkatkan produktivitas usahatani anggota kelompok. Kebutuhan petani telah dihitung pada awal masa tanam oleh pengurus kelompok tani. Akan tetapi, kemampuan kelompok 
tani dalam menyediakan sarana produksi terbatas, sehingga petani sering kali harus mencukupi kekurangan sarana produksi seperti pupuk maupun pestisida secara mandiri.

\section{Peran Efektivitas Penyuluhan dan Kelompok Tani terhadap Kapasitas Petani}

Untuk mengetahui pengaruh efektivitas penyuluhan dan peran kelompok tani terhadap kapasitas petani dilakukan analisis inferensial menggunakaan PLS. Pada proses algoritma menghasilkan Average Varian Extracted $(A V E)$, discriminant validity dan composite reliability $>0,7$ sehingga indikator valid dan reliabel untuk merefleksikan peubah laten. Model pengukuran pada penelitian ini dapat dilihat pada Gambar 2.

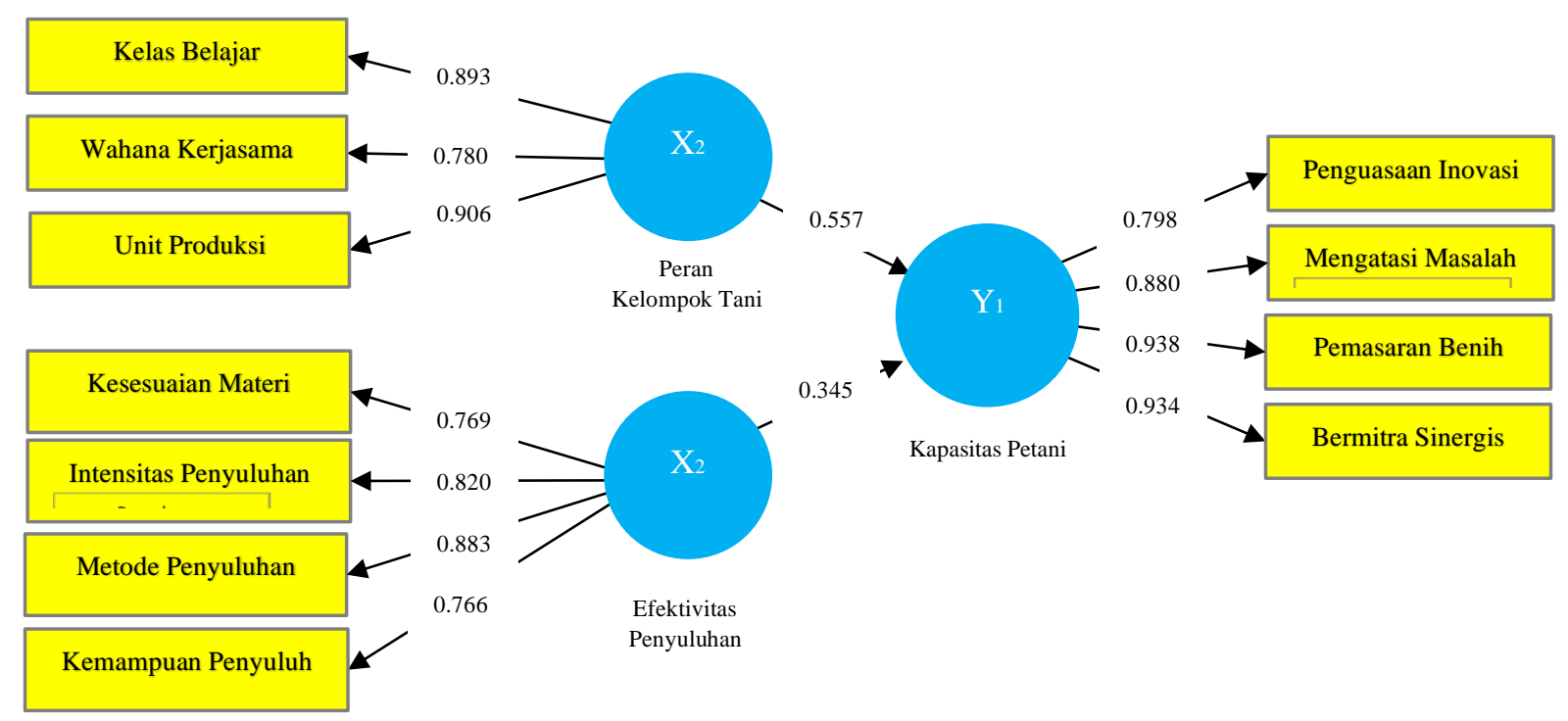

Gambar 2. Model pengukuran tingkat kapasitas petani penangkar benih di Kabupaten Majalengka

Hasil pengujian model struktural menunjukkan signifikansi pengaruh efektivitas penyuluhan dan peran kelompok tani terhadap kapasitas petani penangkar benih. Nilai $\mathrm{R}^{2}$ didapatkan 0,667 artinya 66,7 persen kapasitas petani penangkar benih dipengaruhi oleh efektivitas penyuluhan dan peran kelompok tani, sedangkan sisanya sebesar 33,3 persen dipengaruhi oleh faktor lain yang tidak diteliti dalam penelitian.

Tabel 4. Hasil pengujian model struktural hubungan efektivitas penyuluhan dan peran kelompok tani terhadap kapasitas petani

\begin{tabular}{lcccc}
\hline Peubah Laten Endogen & Peubah Laten Eksogen & T Statistik & Nilai p & \multirow{2}{*}{$\mathbf{R}^{\mathbf{2}}$} \\
\hline Kapasitas Petani & Efektivitas Penyuluhan & 3,701 & $0,000^{*}$ & \multirow{2}{*}{0,667} \\
\cline { 2 - 4 } Penangkar Benih padi & Peran Kelompok Tani & 5,860 & $0,000^{*}$ & \\
\hline
\end{tabular}

\section{Efektivitas Penyuluhan}

Efektivitas penyuluhan memengaruhi secara signifikan terhadap tingkat kapasitas petani dalam usaha penangkaran benih padi. Semakin efektif penyuluhan pertanian dilakukan maka semakin tinggi kapasitas petani penangkar, terutama dalam hal penguasaan teknologi penangkaran benih, pemecahan masalah, pemasaran benih dan bermitra sinergis. Indikator efektivitas penyuluhan yang mempunyai pengaruh tertinggi terhadap kapasitas petani adalah metode penyuluhan $(\lambda=0,883)$, intensitas penyuluhan $(\lambda=0,820)$, kesesuaian materi $(\lambda=0,769)$, dan kemampuan penyuluh $(\lambda=0,766)$. Hal ini berarti bahwa metode penyuluhan dan intensitas penyuluhan lebih dominan membentuk efektivitas penyuluhan untuk memengaruhi kapasitas petani. Oleh karena itu, peningkatan kapasitas petani dalam usaha penangkaran benih padi dapat dilakukan melalui penggunaan metode penyuluhan yang tepat serta peningkatan intensitas penyuluhan kepada petani.

Pada pelaksanaan Program DMB, penyuluh menyampaikan materi penyuluhan melalui sekolah lapang, demplot serta temu lapang. Materi sekolah lapang adalah proses produksi benih dari budidaya, sertifikasi benih, serta penanganan pasca panen. Petani terlibat aktif dalam penggunaan biodekomposer, menanam 
menggunakan rice transplanter dan panen menggunakan combine harvester. Penggunaan alsintan ini tidak efektif karena tanah berlumpur dan benih padi yang tidak sesuai. Selain itu, terdapat anggapan penggunaan mesin combine harvester membutuhkan modal besar dan dapat menghilangkan keakraban di antara para petani karena panen biasanya dilakukan secara bergotongroyong antar sesama petani (Listiana et al., 2020).

Demplot varietas padi memperlihatkan kinerja VUB padi sehingga petani dapat menilai kelebihan agronomis dan organoleptik varietas seperti Inpari 32, Inpari 39, Inpari 42, Inpari 45, Padjadjaran, Munawacita, Siliwangi, dan Pemelen. Varietas padi yang paling banyak disukai petani adalah Inpari 32, Inpari 42 dan Inpari 45. Pada saat panen, dilakukan temu lapang untuk menunjukkan kinerja teknologi penangkaran benih kepada peserta seperti penyuluh, petani, penangkar dan pedagang benih di Majalengka, Indramayu, dan Sumedang.

Metode sekolah lapang, demplot dan temu lapang membuat petani yakin dan memahami inovasi penangkaran benih. Hal ini sesuai dengan penelitian Purnomo et al., (2015) yang menyatakan metode penyuluhan yang paling efektif dalam transfer teknologi adalah sekolah lapang, temu lapang dan demplot. Penyuluh melakukan kunjungan ke kelompok tani. Petani dan penyuluh berdiskusi mengenai hama dan penyakit, teknologi serta pemasaran benih. Hal ini meningkatkan motivasi petani dalam menerapkan inovasi penangkaran benih padi meningkat.

Penyampaian materi yang sesuai dengan kebutuhan petani melalui metode penyuluhan yang tepat membuat petani menaruh minat dan menerapkan inovasi. Hal ini membuat kapasitas petani dalam kategori sedang cenderung tinggi pada aspek penguasaan inovasi penangkaran benih padi.

Menurut petani, intensitas penyuluh dalam melakukan penyuluhan masih rendah terutama setelah program DMB berakhir. Petani melakukan kunjungan ke kelompok tani hanya setiap bulan sekali. Untuk meningkatkan kapasitas petani, upaya yang dapat dilakukan adalah meningkatkan intensitas penyuluhan di lapangan untuk mendampingi usaha tani petani. Intensitas penyuluh dapat meningkat jika penyuluh tinggal di wilayah binaan sehingga petani dapat menghubungi penyuluh setiap saat. Pemerintah harus mengurangi pekerjaan administrasi penyuluh yang tidak berkaitan langsung dengan perubahan perilaku petani. Frekuensi penyuluhan yang tinggi dengan metode penyuluhan yang tepat, membuat petani menjadi lebih mudah menerima materi penyuluhan. Intensitas anggota kelompok menjadi lebih tinggi dalam kegiatan penyuluhan sehingga dinamika kelompok menjadi lebih baik (Kusnani et al., 2015).

Penyuluh menyampaikan materi penyuluhan sesuai dengan kebutuhan petani. Kebutuhan materi petani adalah teknologi budidaya padi, proses pemupukan dan pengendalian hama dan penyakit. Penyampaian materi penyuluhan melalui sekolah lapang dan demplot. Petani mampu menguasai dan menerapkan inovasi sehingga produksi benih petani tidak lebih rendah dari produksi padi konsumsi.

Kemampuan penyuluh dalam menyampaikan materi penyuluhan tergolong baik. Penyuluh menggunakan bahasa yang sederhana dan memberikan praktek penerapan teknologi. Dengan kemampuan penyuluh yang baik ini kapasitas petani menjadi meningkat. Akan tetapi penyuluh belum optimal dalam memfasilitasi petani bekerjasama dengan pemerintah atau swasta untuk mendapatkan akses pasar dan modal usaha. Hal ini membuat kemampuan petani dalam bermitra sinergis dan mengatasi masalah masih perlu dioptimalkan.

Pembangunan pertanian di Kabupaten Majalengka masih fokus pada aspek peningkatan produksi pertanian seperti pemberian bantuan benih, alsintan, teknologi, saprodi dan perbaikan jaringan irigasi, peningkatan penerapan sistem tanam jajar legowo, penyediaan varietas unggul baru dan penerapan pupuk organik. Keberhasilan kegiatan penyuluhan dapat dilihat dari tingkat kapasitas petani paling tinggi pada aspek penguasaan inovasi penangkaran benih, yang terdiri dari budidaya, rouging, sertifikasi benih dan penanganan pasca panen. Menurut Ragasa (2016), peningkatan pendapatan petani tidak hanya tergantung produksi tetapi akses pasar juga menentukan. Hal ini sejalan dengan Amanah (2007) yang menyatakan bahwa salah satu aspek penyelenggaraan penyuluhan harus mampu mengembangkan kesadaran, kapasitas diri dan kelompok serta penerapan prinsip keberlanjutan kegiatan dari segi sosial, ekonomi dan lingkungan. Oleh karena itu, penyuluhan harus meliputi aspek budidaya dan manajerial.

\section{Peran Kelompok Tani}

Peran kelompok tani mempunyai hubungan positif dan pengaruh yang nyata terhadap tingkat kapasitas petani. Semakin baik kelompok tani dalam menjalankan perannya maka semakin tinggi pula kapasitas petani. Hal ini 
sejalan dengan penelitian Sawitri \& Nurtilawati, (2019) yang menyatakan peran kelompok tani memberikan pengaruh positif terhadap peningkatan kapasitas petani. Indikator peran kelompok yang paling kuat merefleksikan peran kelompok tani adalah peran sebagai unit produksi dengan nilai factor loading 0,906 diikuti sebagai kelas belajar $(\lambda=0,893)$ dan wahana kerjasama $(\lambda=0,780)$. Hal ini mempunyai makna bahwa peran kelompok tani sebagai unit usaha menghasilkan benih produksi dan menyediakan saprodi lebih dominan dalam membentuk peubah peran kelompok tani untuk memengaruhi kapasitas petani.

Kelompok tani dapat melaksanakan perannya sebagai kelas belajar dengan baik. Kelompok mengetahui kebutuhan belajar petani dan melaksanakan kegiatan pembelajaran dengan baik. Ketika ada permasalahan di lapangan, kelompok tani mencari solusi dengan melibatkan penyuluh pertanian dan nara sumber yang kompeten. Petani merasakan peran kelompok tani dalam meningkatkan kapasitas petani dalam penguasaan inovasi penangkaran benih. Hal ini senada dengan penelitian Hadi et al., (2019) menyatakan bahwa peran kelompok tani cukup mampu dalam mendorong anggotanya untuk menerapkan sistem pertanian organik.

Kelompok tani memberikan pendampingan penerapan teknologi kepada anggota sehingga petani dapat bertanya secara langsung jika ada permasalahan. Kelompok tani memberikan sarana produksi untuk menghasilkan benih padi. Hal ini mampu meningkatkan kapasitas petani dalam mengatasi masalah petani untuk mendapatkan sarana produksi.

Motivasi awal pembentukan kelompok tani adalah untuk memperkuat posisi tawar petani, terutama dalam pengadaan sarana produksi dan pemasaran hasil secara kolektif untuk meningkatkan efisiensi usaha (Nuryanti \& Swastika, 2016). Akan tetapi, kemampuan kelompok tani terbatas untuk menampung semua produksi benih padi dan memasarkannya ke pasar. Oleh karena itu petani kadang menjual benih padi dengan harga konsumsi. Kemampuan petani dalam mengatasi masalah dan bermitra sinergis perlu dioptimalkan. Jaminan pasar menjadi faktor yang mempengaruhi petani dalam menerapkan suatu teknologi (Hadi et al., 2019). Karena dengan bermitra, kelompok dapat mendapatkan jaminan pasar untuk memasarkan produk usahanya. Menurut Saptana et al., (2016), kemitraan usaha yang dikembangkan melalui proses sosial yang matang dan rasa saling percaya di antara pelaku agribisnis dapat mewujudkan keunggulan komparatif menjadi keunggulan bersaing.

\section{KESIMPULAN}

Tingkat kapasitas petani pada aspek penguasaan inovasi penangkaran, mengatasi masalah, pemasaran benih dan bermitra sinergis berada pada kategori sedang. Produktivitas petani penangkar tidak turun setelah melaksanakan usahatani penangkaran benih karena petani mampu menerapkan teknologi penangkaran benih. Tingkat efektivitas penyuluhan pertanian dalam aspek kesesuaian materi, metode penyuluhan dan kemampuan penyuluh berada pada kategori sedang dan intensitas penyuluhan berada pada kategori rendah. Penyuluh menyampaikan teknologi penangkaran benih sesuai dengan minat dan kebutuhan petani. Petani dapat melihat dan mempraktekkan teknologi budidaya dan penanganan pasca panen walaupun intensitas penyuluhan hanya sebulan sekali. Hal ini didorong kelompok tani mampu melaksanakan peran sebagai kelas belajar, wahana kerjasama dan unit produksi yang berada pada kategori sedang. Efektivitas penyuluhan dan peran kelompok tani mempunyai pengaruh yang nyata dan positif terhadap kapasitas petani penangkar benih. Proses penyuluhan yang meningkatkan partisipasi aktif petani sehingga petani dapat mencoba, melihat dan menilai kinerja teknologi secara langsung dapat meningkatkan kemampuan petani dalam penguasaan teknologi penangkaran benih padi. Kelompok tani mampu melaksanakan proses pembelajaran untuk meningkatkan pengetahuan, sikap dan ketrampilan petani sehingga dapat melengkapi keterbatasan jumlah penyuluh untuk meningkatkan kapasitas petani dalam usaha penangkaran benih padi. Kelompok Penangkar belum memanfaatkan media sosial dan kemitraan secara berkelanjutan untuk mendapatkan modal usaha dan kepastian pasar. Oleh karena itu intensitas penyuluhan menggunakan berbagai metode penyuluhan dengan melibatkan kelompok tani perlu ditingkatkan.

\section{DAFTAR PUSTAKA}

Amanah, S. (2007). Makna Penyuluhan dan Transformasi Perilaku Manusia. Jurnal Penyuluhan, 3(1), $63-67$. https://doi.org/https://doi.org/10.25015/penyuluhan.v3i1.2152

Amanah, S. (2014). Paradigma Penyuluhan dan Pendekatan Pemberdaayaan. Di dalam: Pemberdayaan sosial Petani-nelayan, Keunikan Agroekosistem dan daya saing. Yayasan Pustaka Obor Indonesia.

Anantanyu, S. (2011). Kelembagaan Petani: Peran dan Strategi Pengembangan Kapasitasnya. Jurnal SEPA,

Jurnal Penyuluhan | Vol. 17 (02) 2020 | 271 
$7(2), 102-109$.

Erwandri, E. (2020). Analisis Kelayakan Usahatani Penangkaran Benih Padi di Desa Lubuh Ruso, Kecamatan Pemayung, Kabupaten Batang Hari. Journal of Scientech Research and Development, 2(2), 71-78. http://idm.or.id/JSCR

Fatchiya, A. (2010). Tingkat Kapasitas Pembudidaya Ikan dalam Mengelola Usaha Akuakultur secara Berkelanjutan Fish Farmer Capacity to Manage of Aquabusiness Sustainability. Jurnal Penyuluhan, 6(1), 74-83. https://doi.org/https://doi.org/10.25015/penyuluhan.v6i1.10667

Ghosali, H., \& Latan. (2015). Partial Least Square: Konsep, Teknik dan Aplikasi menggunakan Smart PLS 3.0 (Edisi 2). UNDIP.

Hadi, S., Prayuginingsih, H., \& Akhmadi, A. N. (2019). Peran Kelompok Tani dan Persepsi Petani Terhadap Penerapan Budidaya Padi Organik di Kabupaten Jember. Jurnal Penyuluhan, 15(2), 154-168. https://doi.org/10.25015/15201918492

Haryanto, Y., Sumardjo, S., Amanah, S., \& Tjitropranoto, P. (2020). Factors Affecting the Capacity and the Interdependence of Progressive Farmers in West Java Indonesia. Jurnal Penyuluhan, 16(1), 106-121. https://doi.org/10.25015/16202026770

Iskandar, E., Amanah, S., Hubeis, A. V. S., \& Sadono, D. (2020). The Prominent Role of Agricultural Extension System on Cocoa Agribusiness Development in Aceh, Indonesia Peran Utama Sistem Penyuluhan Pertanian dalam Pengembangan Agribisnis Kakao di Aceh, Indonesia. 16(02), 199-212. https://doi.org/https://doi.org/10.25015/16202029298

Kusnani, D., Muljono, P., \& Saleh, A. (2015). Dinamika Kelompok Penerima CSR PLN Tarahan Lampung Selatan. Jurnal Penyuluhan, 11(2), 129-142. https://doi.org/https://doi.org/10.25015/penyuluhan.v11i2.10578

Listiana, I., Rangga, K. K., Anggoroseto, P., \& Purwatiningsih, N. A. (2020). Respons Petani terhadap Penggunaan Combine Harvester pada Waktu Panen Padi Sawah di Kabupaten Pringsewu Provinsi Lampung. Jurnal Pengkajian Dan Pengembangan Teknologi Pertanian, 23(3), 259-269. https://doi.org/http://dx.doi.org/10.21082/jpptp.v23n3.2020.p\%25p

Mardikanto, T. (1993). Penyuluhan Pembangunan Pertanian. UNS Press.

Mita, Y. T., Haryono, D., \& Marlina, L. (2018). Analisis Pendapatan Dan Faktor-Faktor Yang Mempengaruhi Pengambilan Keputusan Usahatani Penangkaran Benih Padi Di Kabupaten Pesawaran. Jurnal Ilmu-Ilmu Agribisnis, 6(2), 125-132. https://doi.org/http://dx.doi.org/10.23960/jiia.v6i2.\%25p

Munirudin, A. L., Krisnamurthi, B., \& Winandi, R. (2020). Kajian Pelaksanaan Kemitraan Perkebunan Kelapa Sawit di Kabupaten Kutai Timur ( Studi Kasus di PT . NIKP ). Jurnal Pertanian Terpadu, 8(2), 211225. https://doi.org/https://doi.org/10.36084/jpt..v8i2.262

Nurmalia, N., Lutfiyanah, A., Minarni, M., Prastiyo, A., Putra, M. A. P., Darwita, N., \& Ayu, W. (2020). Peningkatan Kapasitas Pembudidaya Ikan Melalui Optimalisasi Fungsi Wahana Pembelajaran Kelompok. Jurnal Penyuluhan Perikanan Dan Kelautan, 14(3), 301-314. https://doi.org/10.33378/jppik.v14i3.224

Nuryanti, S., \& Swastika, D. K. S. (2016). Peran Kelompok Tani dalam Penerapan Teknologi Pertanian. Forum Penelitian Agro Ekonomi, 29(2), 115-128. https://doi.org/10.21082/fae.v29n2.2011.115-128

Permentan. (2013). Peraturan Menteri Pertanian Nomor 82 tahun 2013 tentang Pedoman Pembinaan Kelompok Tani dan Gabungan Kelompok Tani. Kementerian Pertanian.

Purnaningsih, N. (2007). Strategi Kemitraan Agribisnis Berkelanjutan. Sodality:Jurnal Transdisiplin Sosiologi, Komunikasi Dan Ekologi Manusia, 01(03), 393-416. https://doi.org/https://doi.org/10.22500/sodality.v1i3.5899

Purnomo, E., Pangarsa, N., Andri, K. B., \& Saeri, M. (2015). Efektivitas Metode Penyuluhan dalam Percepatan Transfer Teknologi Padi di Jawa Timur. Jurnal Inovasi Dan Teknologi Pembelajaran, 1(2), 191-204. https://doi.org/http://dx.doi.org/10.17977/um031v1i22015p191

Putra, R., Saleh, A., \& Purnaningsih, N. (2016). Hubungan Peran Kelompok Tani dengan Kapasitas Petani Penangkar Benih Padi Sawah (Oriza sativa L) di Kabupaten Lampung Timur. Jurnal Komunikasi Pembangunan, 14(1), 112-128. https://doi.org/https://doi.org/10.46937/14201613555

Ragasa, C. (2016). Challenges in Implementing a Small-Scale Farmers ' Capacity-Building Program. Development Strategy and Governance Division. International Food Policy Research Institute.

Rimbawati, D. E. manggala, Fatchiya, A., \& Sugihen, B. G. (2018). Dinamika Kelompok Tani Hutan 
Agroforestry di Kabupaten Bandung. Jurnal Penyuluhan, 14(1), 92-103. https://doi.org/10.25015/penyuluhan.v14i1.17223

Saleh, A., Putra, R., \& Purnaningish, N. (2016). Strategi Meningkatkan Kapasitas Penengkar Benih Benih Padi Sawah (Oriza Sativa L) Dengan Optimalisasi Kelompok Tani. Jurnal Komunikasi Pembangunan, 14(1), 12-35. https://doi.org/https://doi.org/10.46937/14201613548

Saptana, N., Sunarsih, N., \& Indraningsih, K. S. (2006). Mewujudkan Keunggulan Komparatif Menjadi Keunggulan Kompetitif Melalui Pengembangan Kemitraan Usaha Hortikultura. Forum Penelitian Agro Ekonomi, 24(1), 61-76. https://doi.org/10.21082/fae.v24n1.2006.61-76

Sawitri, B., \& Nurtilawati, H. (2019). Kapasitas Petani Padi dalam Penerapan Teknologi Pengelolaan Tanaman Terpadu (PTT) di Kecamatan Tamansari Kabupaten Bogor Jawa Barat. Jurnal Penyuluhan Pembangunan, 1(1), 26-43. https://doi.org/10.34145/jppm.v1i1.13

Slamet, M. (2001). Paradigma Penyuluhan Pertanian dalam Era Otonomi Daerah. Universitas Andalas.

Sucihatiningsih. (2010). Model Penguatan Kapasitas Kelembagaan Penyuluh Pertanian dalam Meningkatkan Kinerja Usahatani Studi Empiris di Provinsi Jawa Tengah. Jurnal Agro Ekonomi, 2(1), 13-29. https://doi.org/https://doi.org/10.23917/jep.v11i1.332

Suratini, Muljono, P., \& Wibowo, C. T. (2021). Pemanfaatan Media Sosial untuk Mendukung Kegiatan Penyuluhan Pertanian di Kabupaten Minahasa Provinsi Sulawesi Utara. 17(01), 12-24. https://doi.org/https://doi.org/10.25015/17202132302

Tahitu, M., Saleh, A., P. Lubis, D., \& Susanto, D. (2016). Strategi Pengembangan Kapasitas Pengelola Sagu Di Maluku Tengah Provinsi Maluku. Sosiohumaniora, 18(1), 39-46. https://doi.org/10.24198/sosiohumaniora.v18i1.9355

Tin, H. Q., Struik, P. C., Price, L. L., Tuyen, N. P., Hoan, N. P., \& Bos, H. (2010). Increase of Farmers' Knowledge through farmer seed production schools in Vietnam as assessed on the basis of ex-ante and ex-post tests. Journal of Agricultural Education and Extension, 16(3), 229-247. https://doi.org/10.1080/1389224X.2010.489766

Tjitropranoto, P. (2005). Pemahaman Diri, Potensi/Kesiapan Diri, Dan Pengenalan Inovasi. Jurnal Penyuluhan, 1(1), 62-67. https://doi.org/https://doi.org/10.25015/penyuluhan.v1i1.2103

UNDP. (2008). Capacity Development Practice Note. In Capacity Development Practice Note (Kanni Wign). United Nation Development Programme.

Van den, B., \& Hawkins, H. (1999). Penyuluhan Pertanian. Kanisius. 